\title{
Healthy Modern Landscape Inherited from Hakka Culture
}

\author{
Huang Hui ${ }^{1}$, Gao Ruofei ${ }^{2}$ and Kang Xiaoyong ${ }^{3, a}$ \\ ${ }^{1}$ Associate Professor of Shenzhen Polytechnic, China \\ ${ }^{2}$ Doctor of Chiba University, Japan \\ ${ }^{3}$ Lecturer of Shenzhen Polytechnic, China
}

\begin{abstract}
The Hakka modern landscape is guided by its spirit of ambition, optimism, tolerance, and enterprising. The Meizhou Ruishan Agricultural and Ecological Garden Project (phase 1) combines the attributes of colors, materials and forms from the traditional Hakka architecture, Hakka culture, and the healthy landscape as a general concept and study. Thus, a new concept of modern Hakka landscape has been put forward through practice.
\end{abstract}

\section{Introduction}

Hakka culture is not only diverse but also unique [1]. After several ethnic migrations, Hakka people in the present day comprises mainly of Han nationality branches. Settled in the southern environment, through cultural interaction and permeability, Hakka people posses several characteristics of nearby local southern ethnics such as Baiyue and Yaoshe, while still retaining the traditional central plains culture as their main practice.

Practical activities in Meizhou Ruishan Agricultural and Ecological Garden (phase 1) have been carried out in order to promote the prosperity of regional culture, as well as the concept of healthy landscape. Attempting to introduce a new concept of healthy modern landscape based on the cultural and spiritual heritage of Hakka culture and the application of healthy landscape, Meizhou, recognized as the capital of all Hakkas, has been visited and studied. The colors, materials, and forms inherited from traditional Hakka architecture have been analyzed on a large scale.

\section{Typical Hakka culture characteristics}

In 2013, the worldwide Hakka population is 55 million, including 45 million found in China. The rest of the population reside mostly in Malaysia, Indonesia, Thailand, Singapore, and Burma.

The impact of cultural transfer during population migration and the raw nature of Southern mountainous cultures are brought together to form an intercultural Hakka community. However, despite its cultural diversity, Hakkas still root deeply in Confusinism, which preaches that human beings cannot be separate from nature. Mr. Ge Jianxiong said: "Since the purpose of migration is to settle down, people have to make a choice in culture. They can accept the culture which they migrate to so that they can melt into it; or they have to adhere to their own culture so as to carry it out among

\footnotetext{
${ }^{\mathrm{a}}$ Corresponding author : 44744093 @qq.com
} 
the local people." [2] The following characteristic features are manifested by Hakkas when it comes to architecture, food, and custom:

- Central Plain cultural heritage

- Extensive collection of diversified cultures

- Unique migration culture

\section{Traditional Hakka architecture: colors, materials and forms}

Based on the investigation, the authors have extracted the colors, the surroundings, architectural forms, and material language of typical Hakkas buildings, and their application in modern Hakkas landscapes.

- Blue mountains and green rivers are assessed as environmental setting, integral colors with oxford ochre, gray and brown as dominant hues, entranceway with emphasis on gray and white, and interior decoration embellished with the gorgeous colors like red, yellow, and cyan. Application in landscapes should look after both sides of limited use (background colors and decoration colors) and widespread use (entranceway colors and integral colors of hard landscape), thereby laying the foundation for further correlated researches on the materials embodying Hakkas culture in landscapes.

- The spatial structure with plants enclosing hard landscape are prioritized. The quadratic form in the spatial structure in the facade of entranceway and hard space are also prioritized.

- Definition of soft and hard landscape is accomplished by grey granite and tile. Hard pavement gives priority to river gravel which is good in water permeability. China fir and black bricks are used to shape different kinds of facilities and structures.

\section{Healthy landscape}

Health refers not only to physical health of human body, but also to mental health and the health of social relations. As the WHO (World Health Organization) definition of health goes, "Health is a state of complete physical, mental and social well-being and not merely the absence of disease or infirmity." Based on research findings on health-related landscapes since 1990s, the authors outlined three basic functions of healthy landscapes.

\subsection{Improving body functions}

Environments featuring plant richness can promote children's and adults' enthusiasm for exercise [3][4], and make them voluntarily extend the time of exercise[5]. Strolling through forests can substantially increase the activity of natural killer cells and the quantity of anti-cancer active proteins, and decrease the secretion of adrenal hormones. While in urban environments dominated by hard landscapes, walking can produce no such effect [6].

\subsection{Shaking off weariness and tedium}

Studies have found that green landscape can make people relaxed. In accordance with relevant principles of physiology and psychology, in particular in medical premises, patients more frequently exposed to green landscape can expect shorter hospital stays and a relevant normal blood pressure [7], as well as a more positive attitude [8].

\subsection{Stress-relieving}

Studies have found that in places with green landscape or water, only non-subjective attention is consumed, and the direct attention can be recovered. In contrast, in environments lack of green and full with artificial stimulations, people have to consume large amount of active attention. Enjoying the beauty of green landscape, or resting or exercising in green landscape can relieve stress and recover 
attention [9]. Children will express higher creativity, self-discipline and attentiveness in green landscapes [10][11][12].

In general, healthy landscapes can be summarized as follows: under the guideline of medical science, environmental psychology, behavioral psychology, horticultural therapy, and traditional science of health preservation, with healthy people and sub-healthy people, as well as people of different age groups, physical conditions and psychological health as the target groups, utilize the health care factors of different landscape elements to the full extent, and establish and maintain an environment good for physical and psychological health, so as to promote the interaction between users and landscapes, comprehensively adjust the physical and psychological status of users, resolve somatopsychic disorders to a possible extent, enhance the awareness of self-care and life cultivation and health preservation, and make the users comfortable and healthy both physically and psychologically.

Healthy landscapes take the form, in particular, of the applications of landscape plants with volatile chemical components in landscapes. Based on the functions of volatile chemical components, the landscape plants can be classified into three groups: plants for health and medical care [13][14][15], plants for sterilization, insecticide and desinsectization [16], and plants for absorbing toxic gases [17].

\section{Application practice in Ruishan Agricultural and Ecological Garden}

Known as "the capital of Hakkas in the world", Meizhou in Guangdong Province is the hometown of Hakkas. It witnesses the formation and development of the Hakka subgroup and Hakka culture.

Ruishan Agricultural and Ecological Garden is located in Zhourui Town at the south-west boundaries of Dabu County in Meizhou, and bounded to the northwest by Yinjiang Town. As a key node along the world-famous tourist route of Hakka culture in the intersection of the Economic Zone on the west side and the Pearl River Delta Economic Zone, the Garden is within 40 minutes' drive from downtown Meizhou, and only 30 minutes drive to Dabu County. Famous tourist destinations such as Dama Town, Songkou Town and Yanyang Town are all within the "one hour sphere of life".

\subsection{Design objective}

The landscape of the ecological garden focuses on health and adopts concepts of Hakka culture and healthy landscape based on the quality groundwater resources in the field and the original favorable ecological environment, to develop the ecological garden into a healthy camp with Hakka characteristics that is famous in Meizhou, Guangdong, and South China.

\subsection{Design process}

The landscape design of the project took about one year, with many on-site design exchanges conducted. Designers had reached agreement on the design objective, Party A's intention, existing problems about the site, the expression of Hakka factors, and users. They also made a 1:100 scale model of the innovative waterscape to verify the result.

\subsection{Features of the site}

The garden was transformed from a tree farm with a fantastic natural ecological environment. The purpose of landscape design is to make visitors feel comfortable while enjoying more health, tranquility and mildness in a natural oasis. The test by a professional organization shows that the groundwater source of the ecological garden is of metasilicic acid. The water quality is similar to that in the Bama village in Guangxi, where most people live long. The metasilicic acid mineral water is 
very beneficial to the human body. That's why it is well known as the most high-end and valuable mineral water. It has three characteristics as below:

- Beneficial microelements.

- Natural alkalescence.

- Balance containing of various mineral elements.

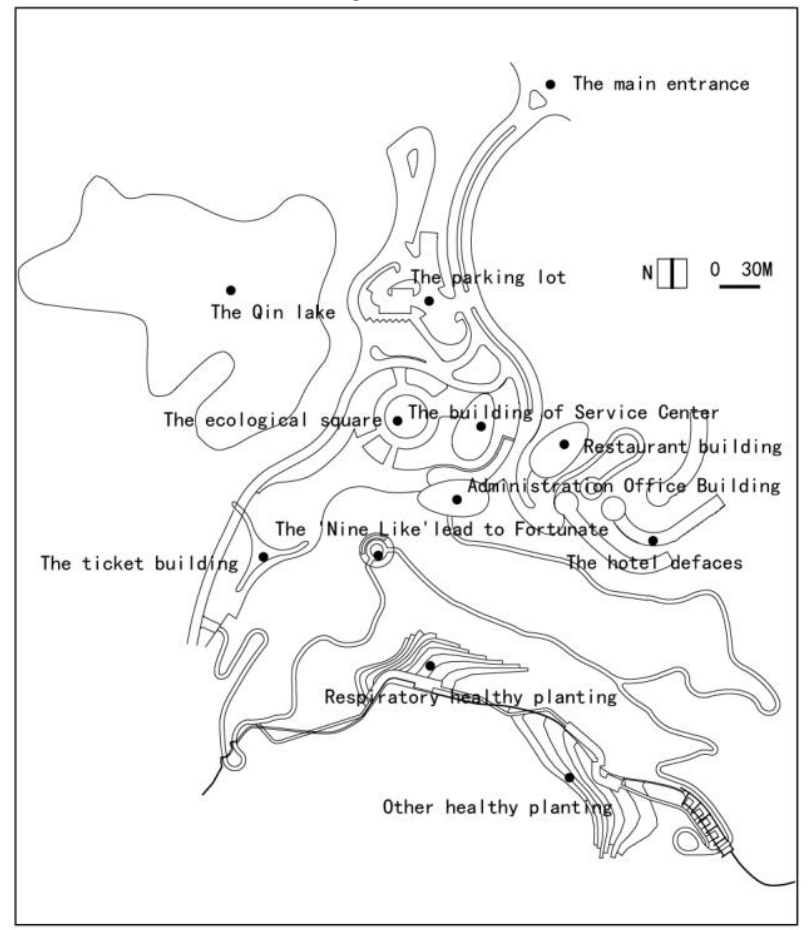

Figure 1 Plan of Ruishan Agricultural and Ecological Garden (phase I)

\subsection{Design elements}

Phase I of the ecological garden refers to the "Qin Lake Zone" and "Ruixiang Valley" of the "Yungu Zone" which are expected to open in October 2017 (Figure 1). The "Lyre Lake Zone" is located at the main entrance of the ecological garden. With focus on the "Lyre Lake", the form of surrounding eucalyptuses and pinus massoniana forests are improved to form a perfect pattern of sightseeing: mountains (natural landscape) - buildings (artificial landscape) - lakes (natural artificial landscape).

The "Ruixiang Valley" of the "Yungu Zone" are mainly decorated with healthy plants. A wooden trestle is built along the stream. Areas used for growing respiratory care plants and other health care plants are also provided. In addition, a new road for electromobiles is created based on the existing land form. It goes from the entrance at the west side of the valley to the hotel buildings at the east side and through the administrative office buildings. The waterscape across the road for electromobiles presents the auspicious sign of longevity. It makes the road more attractive while achieving a bridge for the "Ruixiang Valley" and "Qin Lake".

Modern Hakka architectures which are built based on the design of typical round earthen building bring benefits of preventing cold air from valley, increased use of space, and less sunshine dead zone, which are more suitable for the settlement pattern of hotels. Hotel buildings in the "Qin Lake Zone" are built around the mountain. Together with the oval service center, dining hall and office buildings, they constitute a shape of Ruyi, which symbolizes good luck and longevity. The GRC stainless steel mosaic externally veneered roofs and glass walls are adopted for three office buildings. In addition, metal mosaic veneered roofs are also adopted for the hotel buildings. In the green background, the buildings shine like dews on a lotus leaf. 
Hakka people's traditional settlement areas were located in hilly areas. The hilly area of Meizhou accounts for more than $50 \%$ of that of the whole city. Such special geological formation enables the abundance in stones including landscape stones and granites. Local stones are extensively applied in the foundation of traditional Hakka architectures [16]. Hard landscapes of the "Qin Lake Zone" and "Ruixiang Valley" take full advantage of natural stone resources in Ruishan. With less artifacts applied, a more attractive landscape space is formed. Meanwhile, colors with territorial nature and Ruishan characteristics are exploited to match with the nature and Hakka culture. Local stones are widely used in the circular plaza and landscape along the lake in the "Qin Lake Zone". For traditional Hakka architectures, bamboos, woods, red clays, stones and other natural materials are mainly used. However, artificial materials are mainly exploited in modern Hakka architectures for the purpose of modeling and cost control. The landscape structures made of natural materials embody the correspondence between modern Hakka landscapes and traditional culture as well as nature. The combined application of these materials reflects the traditional Hakka culture to some extent. (Figure 2)

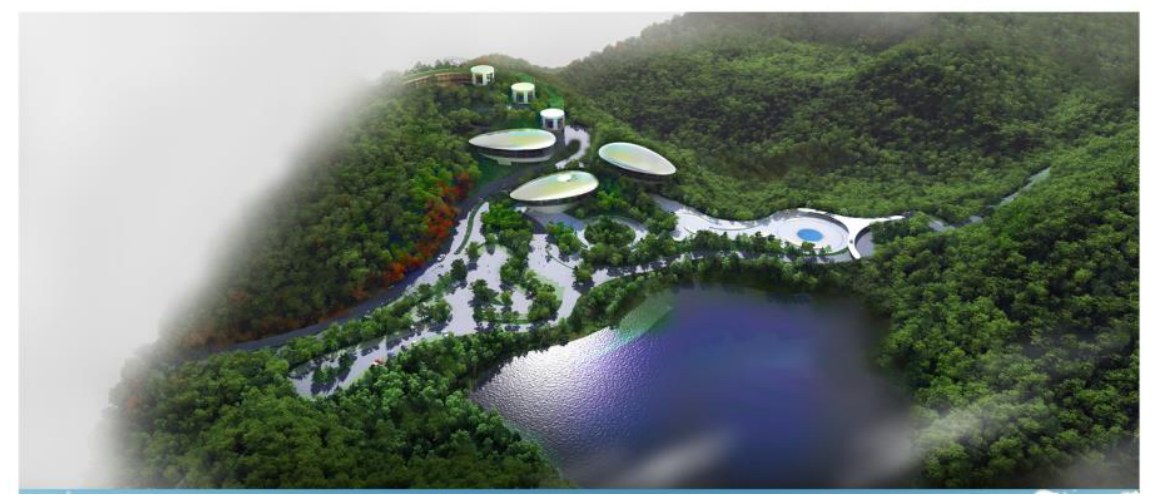

Figure 2 Ruishan Agricultural and Ecological Garden (phase I)

The abundant use of healthy plants in the "Ruixiang Valley" of the "Yungu Zone" agrees with the garden's theme - health . In the context that health is gradually incorporated into state policies [17], adoption of more healthy plants in landscape design adapts to needs of social development in China, especially in southern China. It also goes well with the diversity and pioneering spirits of Hakka culture as well as embodies the existence and improvement of Hakka. In the light of prevalent respiratory diseases suffered by people live in modern cities, the area used for growing respiratory care plants mainly consists of the jasmine, Chinese rose, rosemary, etc. The area used for growing other healthy plants mainly consists of the sage, lavender etc. As it is dominated by the existing eucalyptuses and aromatic plants, the valley is called "Ruixiang Valley". Table 1 below listed the effects of health plants in the "Ruixiang Valley".

Table 1: Healthy Plants of "Ruixiang Valley"

\begin{tabular}{|c|l|l|c|c|l|l|c|}
\hline \multicolumn{4}{|c|}{ Respiratory Health-Types } & \multicolumn{4}{c|}{ Other Health-Types } \\
\hline No. & English & Latin & Effect & No. & English & Latin & Effect \\
\hline 1 & Prynne & $\begin{array}{l}\text { Michelia } \\
\text { alba }\end{array}$ & $\begin{array}{c}\text { Ceasing cough } \\
\text { Suppressing asthma } \\
\text { Expectorant }\end{array}$ & 1 & Mason pine & $\begin{array}{l}\text { Pinus } \\
\text { massoniana }\end{array}$ & $\begin{array}{c}\text { Distributing fine } \\
\text { Pythoncidere }\end{array}$ \\
\hline 2 & Manglietia & $\begin{array}{l}\text { Manglietia } \\
\text { fordiana }\end{array}$ & $\begin{array}{c}\text { Antitussive } \\
\text { Expectorant }\end{array}$ & 2 & Chinese fir & $\begin{array}{l}\text { Cunninghamia } \\
\text { lanceolata }\end{array}$ & $\begin{array}{c}\text { Distributing fine } \\
\text { Pythoncidere }\end{array}$ \\
\hline 4 & Velvet & $\begin{array}{l}\text { Magnolia } \\
\text { coco }\end{array}$ & $\begin{array}{c}\text { Antitussive } \\
\text { Expectorant } \\
\text { Suppressing asthma }\end{array}$ & 3 & $\begin{array}{l}\text { Lemon } \\
\text { eucalyptus }\end{array}$ & $\begin{array}{l}\text { Eucalyptus } \\
\text { citriodora }\end{array}$ & Antibacterial \\
\hline Osmanthus & $\begin{array}{l}\text { Osmanthus } \\
\text { fragrans }\end{array}$ & Suppressing asthma & 4 & Nagi & Nageia nagi & $\begin{array}{c}\text { Calming } \\
\text { Relaxing and the } \\
\text { regulation of mood }\end{array}$ \\
\hline
\end{tabular}




\begin{tabular}{|c|c|c|c|c|c|c|c|}
\hline 5 & $\begin{array}{l}\text { Tianzhu } \\
\text { laurel }\end{array}$ & $\begin{array}{l}\text { Cinnamomum } \\
\text { japonicum }\end{array}$ & $\begin{array}{l}\text { Suppressing asthma } \\
\text { Antitussive } \\
\text { Expectorant }\end{array}$ & 5 & Camphor & $\begin{array}{l}\text { Cinnamomum } \\
\text { camphora }\end{array}$ & $\begin{array}{c}\text { Antibacterial } \\
\text { Absorbing (SO2, Cl2, } \\
\text { HF, HCL, benzene, O3, } \\
\text { dust) }\end{array}$ \\
\hline 6 & Burmannii & $\begin{array}{l}\text { Cinnamomum } \\
\text { burmannii }\end{array}$ & $\begin{array}{c}\text { Suppressing asthma, } \\
\text { Antitussive } \\
\text { Expectorant }\end{array}$ & 6 & Tallow & $\begin{array}{l}\text { Sapium } \\
\text { sebiferum }\end{array}$ & $\begin{array}{l}\text { Relieving headaches } \\
\text { Refreshing }\end{array}$ \\
\hline 7 & Sweetgum & $\begin{array}{l}\text { Liquidambar } \\
\text { formosana }\end{array}$ & Suppressing asthma & 7 & Magnolia & $\begin{array}{l}\text { Magnolia } \\
\text { denudata }\end{array}$ & $\begin{array}{c}\text { Ceasing cough } \\
\text { Antibacterial } \\
\text { Relieving headaches }\end{array}$ \\
\hline 8 & Schefflera & $\begin{array}{l}\text { Schefflera } \\
\text { heptaphylla }\end{array}$ & $\begin{array}{l}\text { Antitussive } \\
\text { Expectorant }\end{array}$ & 8 & Callistemon & $\begin{array}{l}\text { Callistemon } \\
\text { rigidus }\end{array}$ & $\begin{array}{c}\text { Antitussive } \\
\text { Expectorant } \\
\text { Absorbing (SO2, Cl2, } \\
\text { HCL, dust) }\end{array}$ \\
\hline 9 & $\begin{array}{l}\text { Pittosporu } \\
\text { m }\end{array}$ & $\begin{array}{l}\text { Pittosporum } \\
\text { tobira }\end{array}$ & $\begin{array}{l}\text { Ceasing cough } \\
\text { Suppressing asthma } \\
\text { Expectorant }\end{array}$ & 9 & Aglaia & $\begin{array}{l}\text { Aglaia } \\
\text { odorata }\end{array}$ & $\begin{array}{c}\text { Calming } \\
\text { Relaxing } \\
\text { Regulation of mood, } \\
\text { Hypnotizing } \\
\text { Absorbing SO2 }\end{array}$ \\
\hline 10 & Murraya & $\begin{array}{l}\text { Murraya } \\
\text { exotica }\end{array}$ & $\begin{array}{c}\text { Ceasing cough } \\
\text { Suppressing asthma } \\
\text { Expectorant }\end{array}$ & 10 & $\begin{array}{l}\text { Chinese } \\
\text { rose }\end{array}$ & Rosa cvs. & $\begin{array}{c}\text { Refreshing } \\
\text { Eliminating fatigue, } \\
\text { Hypnotizing }\end{array}$ \\
\hline 11 & Gardenia & $\begin{array}{l}\text { Gardenia } \\
\text { jasminoides }\end{array}$ & Suppressing asthma, & 11 & lavender & $\begin{array}{l}\text { Lavandula } \\
\text { angustifolia }\end{array}$ & $\begin{array}{c}\text { Relieving headaches } \\
\text { Hypnotizing and } \\
\text { Quieting down the mind } \\
\text { Antibacterial } \\
\text { Antitussive } \\
\text { Sterilizing } \\
\end{array}$ \\
\hline 12 & Jasmine & $\begin{array}{l}\text { Jasminum } \\
\text { sambac }\end{array}$ & Suppressing asthma & 12 & Sage & \begin{tabular}{|l} 
Salvia \\
japonica
\end{tabular} & $\begin{array}{c}\text { Bacteriostatic } \\
\text { Bactericidal Anti- } \\
\text { inflammatory } \\
\text { Detoxification } \\
\end{array}$ \\
\hline 13 & Basil & \begin{tabular}{|l} 
Perilla \\
frutescens
\end{tabular} & $\begin{array}{c}\text { Antitussive } \\
\text { Expectorant } \\
\text { Suppressing asthma }\end{array}$ & 13 & Rosemary & $\begin{array}{l}\text { Rosmarinus } \\
\text { officinalis }\end{array}$ & $\begin{array}{c}\text { Refreshing } \\
\text { Driving mosquitoes }\end{array}$ \\
\hline 14 & Thyme & \begin{tabular}{|l} 
Thymus \\
mongolicus
\end{tabular} & $\begin{array}{l}\text { Suppressing asthma } \\
\text { Antibacterial }\end{array}$ & 14 & Mint & $\begin{array}{l}\text { Mentha } \\
\text { haplocalyx }\end{array}$ & $\begin{array}{c}\text { Antibacterial } \\
\text { Exciting hub } \\
\text { Absorbing O3 }\end{array}$ \\
\hline
\end{tabular}

\subsection{Maintenance and management}

Phase I of the ecological garden is maintained by the management personnel of the garden. Usually, the management personnel spend two hours a week in maintaining phase I of the garden. In the period when medicinal herbs need to be replaced, the management personnel spend more time as required. Maintenance of the waterscape is entrusted to professionals. To protect the natural environment of the garden, natural methods are taken for pest control.

\section{Conclusion}

Hakka culture, especially its pioneering spirit, is a key factor for Hakka people to survive and keep vitality. Under the guidance and impact of the essence of Hakka culture and combined with the idea of healthy landscape, Hakka modern landscapes embody a new concept of healthy modern landscape led by Hakka culture. With the development goal of healthy landscape, Hakka modern landscapes will definitely experience a longer life.

The ecological environment of Hakka people's traditional settlement areas lays a foundation for developing Hakka healthy landscape, Hakka culture and spirit provide driving forces, and the abundant rainfall and plant materials in southern China bring application opportunities and various types of materials. 


\section{References}

1. Hegel, Wang Zaoshi. Philosophy of History[M]. Shanghai: Shanghai Bookstore Publishing House, 2001, P572

2. Ge Jianxiong. History of Chinese Population Six Volumes [M]. Shanghai: Fudan University Press, 2002

3. Fjortoft, I.,Sageie, J. The natural environment as a playground for children - landscape description and analyses of a natural playscape [J].Landscape and Urban Planning, 2000, 48(12), 83-97.

4. Sullivan, W. C., Kuo, F. E., DePooter, S. F. The fruit of urban nature vital neighborhood spaces[J]. Environment and Behavior, 2004, 36(5), 678-700.

5. Pennebaker, J. W., \& Lightner, J. M. Competition of internal and external information in an exercise setting[J]. Journal of Personality and Social Psychology,1980,39(1), 165-174.

6. Li, Q., Morimoto, K., Kobayashi, M., Inagaki, H., Katsumata, M., Hirata, Y. Krensky, A. M. Visiting a forest, but not a city, increases human natural killer activity and expression of anticancer proteins[J]. International Journal of Immunopathology and Pharmacology, 2008, 21(1), 117-127.

7. Ulrich, R. S., Simons, R. F., \& Miles, M. A. Effects of environmental simulations and television on blood donor stress[J]. Journal of Architectural and Planning Research, 2003, 20(1), 38-47.

8. Raanaas, R. K., Patil, G. G., \& Hartig, T. Effects of an indoor foliage plant intervention onpatient well-being during a residential rehabilitation program[J]. Hortscience, 2010, 45(3), 387-392.

9. Pretty, J., Peacock, J., Sellens, M., \& Griffin, M. The mental and physical health outcomes of green exercise[J]. International Journal of Environmental Health Research, 2005,15(5), 319-337.

10. Taylor, A. F., Wiley, A., Kuo, F. E., \& Sullivan, W. C. Growing up in the inner city - green spaces as places to grow[J]. Environment and Behavior, 1998, 30(1), 3-27.

11. Taylor, A. F., Kuo, F. E., \& Sullivan, W. C. Coping with add - the surprising connection togreen play settings[J]. Environment and Behavior, 2001, 33(1), 54-77.

12. Taylor, A. F., Kuo, F. E., \& Sullivan, W. C. Views of nature and selfdiscipline: Evidence from inner city children[J]. Journal of Environmental Psychology,2002,22(1-2), 49-63.

13. Yuan Jiamo. Aromatic Plants in Guizhou [M]. Guiyang: Guizhou Science and Technology Publishing House, 1990

14. Zhou Bo, Su Weiwei. Temperament Analysis for Healthy Volatile Substances of Landscape Plants in South of the Five Ridges[D]. Guangzhou: Sun Yat-sen University, 2005

15. Chen Li, Qin Hua, etc. Study on Phytocoenosium Design of Healthy Landscape Plants [J]. Heilongjiang, Northern Horticulture, 2011, (05):152-154

16. Zheng Linsen, Pang Mingyu, Jiang Yihua, etc. Determination of 47 Kinds Healthy Volatile Substances of Landscape Plants [C]. Selected Works of The Fourth National Congress Papers, Collected Works (Volume I). Chinese Society of Landscape Architecture, 2008:189-193

17. Su Xuehen. Plant Landscape [M]. Beijing: China Forestry Publishing House, 1998: 150 